\title{
Forest Matrix Favors the Recovering of Seed Rain in Areas Undergoing Restoration
}

\author{
Bruna Rossi dos Santos ${ }^{1}$ (D) 0000-0003-0010-8057 \\ Jaqueline Alves Pereira ${ }^{2}$ (1) 0000-0001-8433-1306 \\ Marília Luísa Oliveira ${ }^{1}$ (1) 0000-0001-7397-4146 \\ Cinthia Tamara Vieira Rocha ${ }^{1}$ (D) 0000-0002-0739-2081 \\ Vinícius Londe $^{2}$ (ㅇ) 0000-0001-9588-3384
}

\begin{abstract}
We used seed rain to monitor a conserved forest and a 5-6-year-old forest undergoing natural regeneration after fire. The sampled species were classified according to regionality, life forms, dispersal modes, and successional stage, and the forests were compared. The type of forest and time since disturbance had significant effect on the abundance of seeds $-67.3 \%$ being produced in the forest under restoration. Biological diversity was higher in the conserved forest. On the other hand, species richness was not affected by the type of forest, and the species composition was similar between forests. In addition, we found similar proportions of life forms, zoochorous species, and non-pioneer species in the forests. Our study shows that natural regenerating forests can recover different attributes of the seed rain in few years when in forest matrices. Thus, to accelerate restoration and create trustworthy forests we should conserve the remaining mature fragments and use them to facilitate ecological restoration.
\end{abstract}

Keywords: Atlantic Forest, ecological indicators, natural regeneration.

\section{INTRODUCTION AND OBJECTIVES}

Disturbances such as a fire are frequent in areas of remnant vegetation, especially in the Brazilian Cerrado and Atlantic Forest biomes (Araújo et al., 2012). In these biomes, four to five months of ecological drought can be expected every year (Rizzini, 1997). After fires the forest begins to regenerate through colonization by seeds blown or carried from surrounding forests. It then goes through the different stages of secondary succession (Ricklefs, 2008). The ecological succession in tropical forests is characterized as an idiosyncratic process and is directed by many factors (Chazdon et al., 2007) that allow degraded areas to recover naturally, provided there is an adequate habitat matrix of forest fragments, which are a source of seeds surrounding the area (Magnago et al., 2012).

Thus, seed dispersal is an essential mechanism for the recolonization of degraded areas and for a spatial and temporal structure of plant populations (Barbosa et al., 2012). By definition, the deposition or seed rain includes all fruits and seeds that reach a particular site as a result of a variety of dispersal mechanisms (Booth \& Larson, 1998). The seed rain is among the main factors responsible for the initial phase of tropical forest organization and regeneration after ecosystem disturbances (Clark et al., 2001).

Procedures aimed at accelerating the recovery of degraded areas via natural regeneration are necessary given the complexity of tropical ecosystems (Holl et al., 2000). Furthermore, the induction of natural regeneration (also called passive restoration) is low cost since it only creates the conditions necessary for the arrival and establishment of seeds blown from conserved forests fragments in the vicinity (Rodrigues \& Gandolfi, 2004).

Equally important as inducing natural regeneration is the constant monitoring of an area to evaluate its current state, and if the successional processes are taking place correctly. Reviews of forest regeneration provide very useful information for soil management, especially in vegetation recovering after fires (Mitri \& Gitas, 2013). Moreover, these studies allow comparisons and more secure recommendations for soil

\footnotetext{
${ }^{1}$ Centro Universitário de Belo Horizonte (UniBH), Belo Horizonte, MG, Brasil

${ }^{2}$ Universidade Federal de Ouro Preto (UFOP), Ouro Preto, MG, Brasil
} 
management actions (Rodrigues \& Gandolfi, 2004). In this sense, seed rain has been used as an ecological indicator to monitor forest restoration (Martins, 2011). Moreover, seed rains can also be used to assess the conservation status of forest fragments (Piña-Rodrigues \& Aoki, 2014).

In this study, we used seed rain as an ecological indicator to monitor a conserved forest and a 5-6-year-old forest under natural regeneration in the Brazilian Atlantic Forest. Then we answered the following questions: (i) Is there an interaction/ influence of the type of forest and time on the abundance of seeds?; (ii) Does the type of forest have an effect on species richness?; (iii) Does the forest under restoration have comparable biological diversity and species composition to the conserved forest?; (iv) Is the proportion of life forms, zoochorous species, and non-pioneer species in the forest under restoration the same as in the conserved forest? Our prediction is that seed rain is similar between sites because the forest matrix has a positive influence on the forest under recovery.

\section{MATERIALS AND METHODS}

\subsection{Study areas}

The study forests are in the Municipal Ecological Park "Rego dos Carrapatos", in the municipally of Nova Lima, center of Minas Gerais State (Figure 1a). The Park is in the south of the northern slope of Serra do Curral, in the Atlantic Forest biome. Climate in the region is subtropical (Cwa according to Köppen climate classification), with average temperatures ranging from $17.6^{\circ} \mathrm{C}$ (June) to $23.3^{\circ} \mathrm{C}$ (January), and an average annual rainfall of $1,390 \mathrm{~mm}$ (Climate-Data, [2017?]). The Municipal Ecological Park "Rego dos Carrapatos" was donated to the Nova Lima Municipal Government by the AngloGold Ashanti mining company (formerly Morro Velho) in 1996. The Park covers an area of $341,381 \mathrm{~m}^{2}$ and it is adjacent to the city.

We selected two forests at the Ecological Park with different characteristics for seed rain collection: one conserved and another undergoing natural regeneration, separated by about $300 \mathrm{~m}$ (Figure 1b). The conserved forest is further from the urban area and therefore more restricted to human access. The vegetation is in good condition with a predominance of tall trees, thick and typical trunks of more advanced stages of succession, such as Cedrela odorata L. ("cedro") and Lecythis pisonis Cambess ("sapucaia"). The forest layers are well defined, with the occurrence of canopy trees and understory species.

The forest undergoing restoration has been in natural regeneration process since 2005 , when a wildfire destroyed much of the vegetation. In addition, the site has increased anthropogenic pressure due to its proximity to a trail and for being located near an old grazing area dominated by the exotic and invasive grass Melinis minutiflora P.Beauv. (Figure 1b). However, there are some clearings, and lianas and vines are abundant.

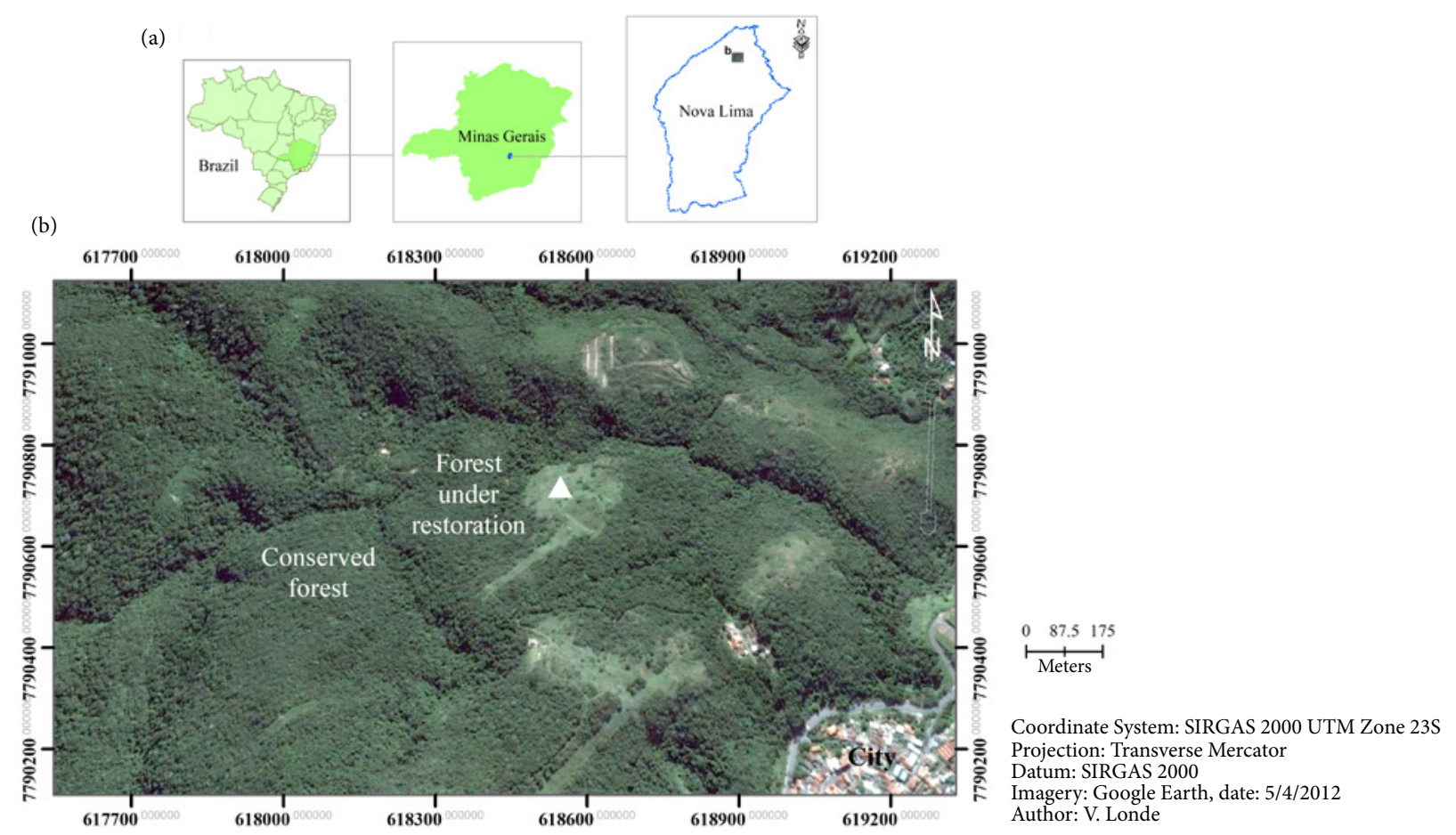

Figure 1. The studied forests are in the municipally of Nova Lima, at the middle of Minas Gerais State, southeastern Brazil (a): two forests were selected at the Municipal Ecological Park "Rego dos Carrapatos" for sampling seed rain: a conserved old-forest and a forest undergoing natural regeneration for 5-6 years (b). The forest under restoration is close to trails and an open area occupied by grasses (white triangle) (b). 


\subsection{Sampling of seed rain}

For sampling the seed rain, we randomly installed 30 seed traps in each forest, about 0.5 hectares. The traps were made of wood, $1 \times 1 \mathrm{~m}$ with a $1 \mathrm{~mm}$ mesh nylon screen and approximately $70 \mathrm{~cm}$ tall. We collected the fallen material in the traps monthly from November 2010 to October 2011. The material was placed in labeled plastic bags and taken to the Botany Laboratory of Centro Universitário de Belo Horizonte, where we separated fruits and seeds.

First, we quantified and divided the fruits and seeds into morphospecies. Then, they were identified according to the level of species or genus consulting specific bibliography and with the help of experts. The identification of botanical families took place according to the rules of the Angiosperm Phylogeny Group IV (2016) and the species or genus according to the Brazilian Flora 2020 (2017). We classified the species regarding their regionality (native or exotic) and life forms (trees, shrubs, herbs or vines/lianas) according to the available data in the Brazilian Flora 2020 (2017). We also classified the species in relation to their dispersal modes in zoochorous and non-zoochorous, and ecological/successional groups (pioneer and non-pioneer species) through literature review (Aquino \& Barbosa, 2009; Ferreira et al., 2013; Gandolfi et al., 1995; Guaratini et al., 2008; Silva et al., 2012).

\subsection{Data analysis}

First, we used the Shapiro-Wilk test to check the normality of the data (raw data and residuals) and the Levene's test to check homoscedasticity. Then, a Generalized Linear Model (GLM, with Gama distribution and Identity function) was performed to answer the first question about the interaction between type of forest (conserved and under restoration) and time (months) (independent variables) on the abundance of seeds (dependent variable) (a factorial design). Next, a t-test was performed to investigate whether the type of forest influenced the species richness. To verify if the forest undergoing restoration had similar biological diversity and species composition in relation to the conserved forest, we calculated the Shannon Diversity Index $\left(\mathrm{H}^{\prime}\right)$ and Jaccard Similarity Coefficient ( $J$ '). Finally, t-tests were used to verify whether the proportion of life forms (shrubs, trees, and vines/lianas), zoochorous species, and non-pioneer species were similar between forests. The statistical analyses were performed in SPSS 23 software, the diversity index $\left(\mathrm{H}^{\prime}\right)$ was performed in PAST 3.15, and the similarity coefficient ( ${ }^{\prime}$ ) was calculated in an electronic spreadsheet.

\section{RESULTS}

In total, 19,114 seeds/fruits were sampled and $67.3 \%$ of them were recorded in the forest under restoration. We found significant differences in the abundance of seeds between forests and over time (months), and an interaction between these factors on the abundance of seeds $\left(\chi^{2} 11=44.6, p<0.001\right)$ (Figure 2). A deposition pattern in seeds was also observed in both forests, with higher abundance of seeds being dispersed in November and December 2010, and September and October 2011 (Figure 2).

We registered 55 species in the forest undergoing restoration and identified 49 of them at the species or genera level. The identified species represented 23 botanical families, with Fabaceae and Malvaceae making up $28.6 \%$ of the total stock (Supplementary material 1). Species richness in the conserved forest was slightly higher $(n=62)$, but the number of identified species was the same $(n=49)$. These species represented 23 families, mainly Bignoniaceae, Fabaceae and Malvaceae (30.6\% of the total) (Supplementary material 1 ).

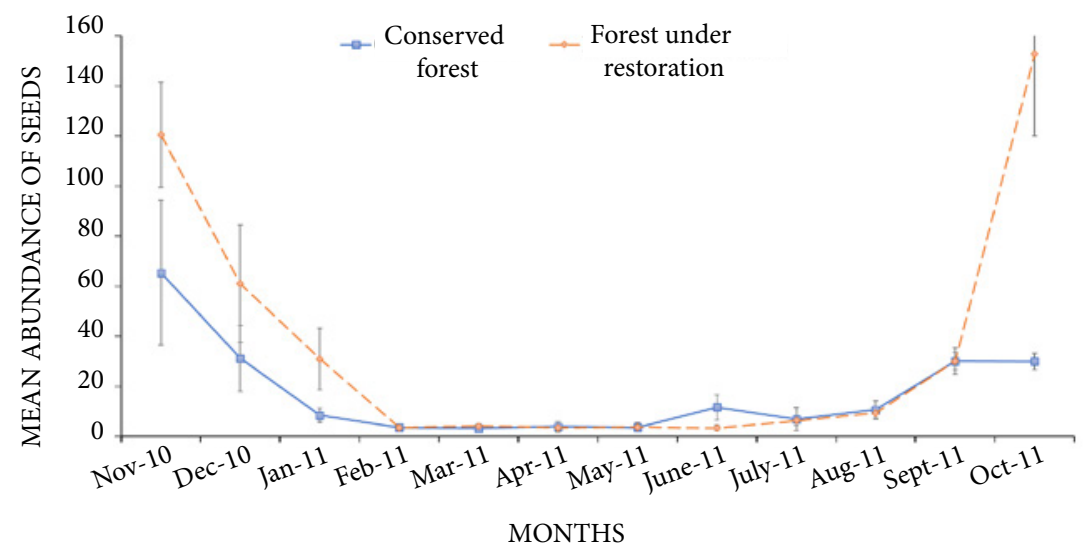

Figure 2. Mean abundance of seeds sampled from November 2010 to October 2011 in a conserved old-growth forest and a forest undergoing restoration at the Municipal Ecological Park "Rego dos Carrapatos," Nova Lima in Southeastern Brazil. Vertical bars represent standard errors. 
The type of forest had no effect on species richness, since it did not differ statistically between them $\left(\mathrm{t}^{58}=1.68, p=0.09\right)$. Regarding biological diversity, we found higher diversity in the conserved forest than in the forest under restoration $\left(\mathrm{H}^{\prime}=2.57\right.$ and 2.3, respectively). About half of species were common in both forests $\left(J^{\prime}=0.46\right)$.

A similar proportion was found for shrubs, trees, and vines/lianas between forests $\left(\mathrm{t}^{58}=0.49, p=0.62 ; \mathrm{t}^{58}=-1.69\right.$, $p=0.97$; and $U=341.5, p=0.09$, respectively) (Figure 3a). The proportion of zoochorous and non-pioneer species was slightly higher in the conserved forest but not statistically significant $\left(\mathrm{t}^{58}=-0.79, p=0.43 ; \mathrm{t}^{58}=-0.44, p=0.66\right.$, respectively) (Figure $3 \mathrm{~b}$ ).

(a)

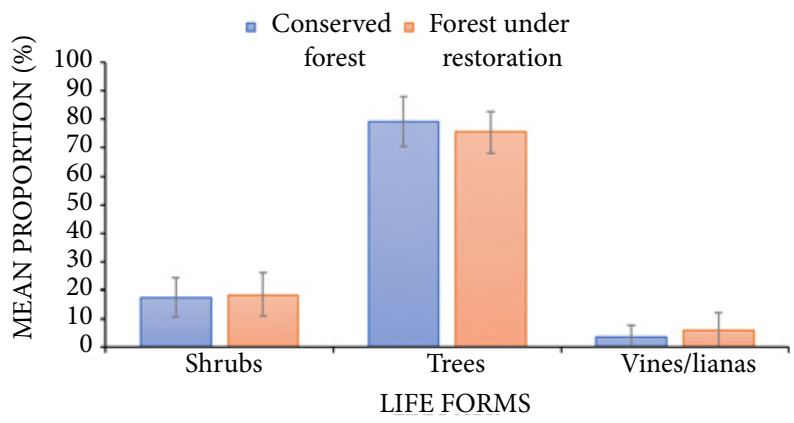

(b)

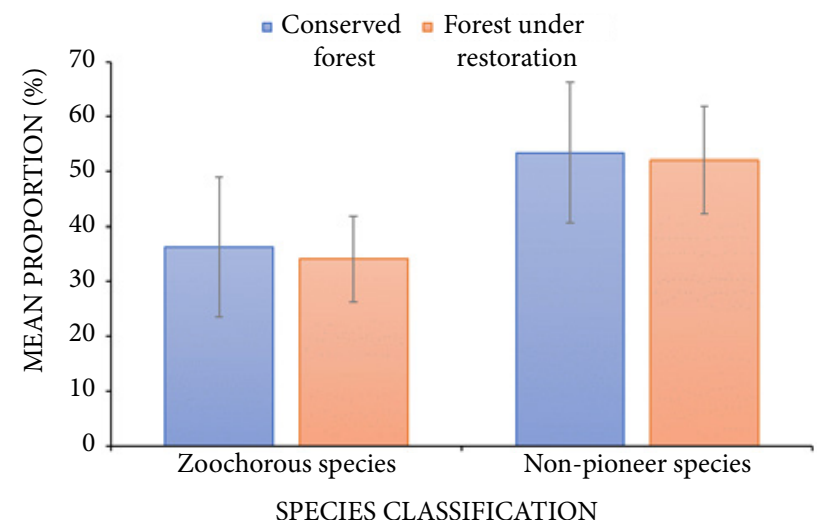

Figure 3. Mean proportion of life forms (a) and zoochorous and non-pioneer species (b) registered in the seed rain of a conserved oldforest and a 5-6-year-old forest under restoration at the Municipal Ecological Park "Rego dos Carrapatos," Nova Lima, in Southeastern Brazil. Vertical bars represent standard deviations.

\section{DISCUSSION}

In our study, the seed rain was significantly affected by the type of forest and time (months), especially in the naturally regenerating forest where abundance of seeds was more variable. This result corroborates other studies in which a greater abundance of seeds fell on soil surfaces of tropical forests in early successional stages than in mature ones (Young et al., 1987). In both areas, the same species (Vernonanthura discolor) contributed the highest amount of seeds. However, in the forest under restoration, this species produced more seeds, suggesting a greater investment of the species in more open areas. Indeed, $V$. discolor is a pioneer and generalist tree adapted to a wide range of environmental conditions (Vibrans et al., 2011).

Vernonanthura discolor, together with Serjania orbicularis and Terminalia glabrescens (a vine and a tree, respectively), comprised $70 \%$ of the seeds collected in the forest under restoration. This certainly contributed to the differences in abundance of seeds and diversity between forests. The Shannon Index results in higher values when the species richness is greater and/or the abundance of species is more even in the community (Magurran, 2004). Beyond the lower evenness, we also found less species in the forest under restoration, which may have influenced the diversity index too.

Besides displaying a similar pattern of seed abundance between old-growth and restoration forests, our study also reinforces the knowledge about the reproductive phenology in tropical forests. The peaks of seed dispersal occurred from September to December in both areas, coinciding with other studies in secondary Brazilian Atlantic Forests (Penhalber \& Vani, 1997). We already expected a great dispersal of seeds in this period because it coincides with the start of the rainy season in the region. The fruit ripening season should coincide with the period that provides the best conditions for successful dispersal and seedling establishment (Rathcke \& Lacey, 1985). Additionally, the above-mentioned species that most contributed with seeds are wind dispersed. Species with this mode of dispersal have small and light propagules that are easily overturned by rain (Penhalber \& Vani, 1997). This can also explain the seeds deposition peaks in this period.

The floristic similarity between our studied forests was high, considering that about half of the species were present in both areas. This result may indicate that the natural regeneration in the forest under restoration has been positively influenced by the species composition of the conserved forest. In this sense, we suggest that little time may be needed for the seed rain composition in naturally regenerating forests located in forest matrices to be comparable to conserved old-growth fragments nearby.

However, besides the proximity to forest fragments, we also need to consider the resilience of the area itself. Some plants must have survived the fire, and with more light and less competition, they regrew and invested in dispersal. Fire 
creates a spatial heterogeneity and a range of local effects in forests, which influence plant reestablishment and other ecological processes (Turner \& Romme, 1994).

The secondary succession processes and the rate of change in species composition vary according to some factors, such as the previous land use, the proximity of older forests, and the availability of seed dispersing fauna (Chazdon, 2013). The heterogeneity of the landscape, the arrangement of borders between ecosystems, and connectivity to other forest fragments are other factors that affect the seed flow between forests (Metzger, 2000). In this way, our findings reiterate the importance of the presence of conserved remnants that actively contribute with native seeds to areas under restoration. For comparison, a 5-year-old rehabilitated riparian forest in a neighboring municipality (Sabará), but far from forest remnants, had very low species richness in the seed rain and half of them were exotic (Londe et al., 2017).

The floristic similarity with the conserved forest and the high species richness that we found in the naturally regenerating area can be considered good indicators of the restoration progress. According to Brown \& Lugo (1990), when the number of species in secondary forests in the initial stage of succession is high, it may be an indication that the opportunities for its establishment are large. The more species an early stage forest can sustain, the greater its role as an "adopted" ecosystem, and more combinations of species can occur (Brown \& Lugo, 1990).

The predominance of tree species in seed rain is in line with other studies carried out in the Brazilian Atlantic Forest (Pivello et al., 2006). We did not observe seeds of herb species in our study, probably due to the height of the seed traps. Vine and lianas were found in both forests (five species in the conserved area and three in the recovery one), all of which were native, and the three species in the forest under restoration were also present in the conserved forest. This result once again underlines the importance of connectivity between restored and conserved remnants because it increases the chances of other life forms to establish in areas under restoration.

In general, the proportion of zoochorous species tends to be lower in successional early stage forests compared to old forests (Brown \& Lugo, 1990); however, we did not notice this difference in our study. Zoochorous dispersal is widely carried out by birds and mammals (Fenner, 1985), and strongly decreases in open (grazing) areas and near the forest edge (Holl, 1999). As the proportion of zoochorous species was the same between forests, we suppose that seed dispersers are not limited to the conserved forest, probably due to the proximity of the areas.
Another positive outcome was the similar proportion of non-pioneer species between forests. This is a good descriptor of recovery and indicates that such species are arriving via dispersion and enriching the recovering community (Martins, 2011). Areas under restoration in good conditions should have abundant seed rain and be rich in different proportions of species (Martins, 2011).

\section{CONCLUSION}

We showed that the type of forest and recovering time are factors that affect the abundance of the seed rain. Moreover, the forest under restoration recovered the species composition, the proportion of life forms and zoochorous and non-pioneer species of the seed rain few years after disturbance. These results suggest the matrix forest must have positively influenced the regeneration of the adjacent forest under restoration. We reinforce the importance of conserving good forest fragments as a source of seeds to accelerate the process of natural regeneration in areas under restoration. This is essential when we consider that natural regeneration is a cheaper method of restoration and (in certain circumstances) can be used to restore large amounts of degraded areas in the tropics.

Finally, to ensure the success and advance of the studied forests and others in similar situations we recommend a few simple but effective steps. For example, it is important to protect the areas from sources of degradation, mainly of new fires and further reduction in the number of trails/ tracks. Moreover, an efficient conservation technique of the Municipal Ecological Park "Rego dos Carrapatos" and others worldwide is making the surrounding human population aware of the ecological importance of these places.

\section{ACKNOWLEDGEMENTS}

We are grateful to Zach Leibowitz for reviewing the English language of our paper.

\section{SUBMISSION STATUS}

Received: 21 Nov. 2017

Accepted: 4 Dec. 2018

Associate editor: Rodrigo Studart Corrêa

(D) 0000-0002-9422-2629

\section{CORRESPONDENCE TO}

\section{Vinícius Londe}

Rua Possidónio da Silva, 1, cave dta., Código Postal 1350-245,

Lisboa, Portugal

e-mail: vlonde.ecologia@gmail.com 


\section{REFERENCES}

Angiosperm Phylogeny Group IV. An update of the Angiosperm Phylogeny Group classification for the orders and families of flowering plants: APG IV. Botanical Journal of the Linnean Society 2016; 181(1): 1-20. 10.1111/boj.12385

Aquino C, Barbosa LM. Classes sucessionais e síndromes de dispersão de espécie arbóreas e arbustivas existentes em vegetação ciliar remanescente (Conchal, SP), como subsídio para avaliar o potencial do fragmento como fonte de propágulos para enriquecimento de áreas revegetadas no Rio Mogi-Guaçu, SP. Revista Árvore 2009; 33(2): 349-358. 10.1590/S0100-67622009000200016

Araújo FM, Ferreira LG, Arantes AE. Distribution patterns of burned areas in the Brazilian biomes: an analysis based on satellite data for the 2002-2010 period. Remote Sensing 2012; 4(7): 1929-1946. $10.3390 / \mathrm{rs} 4071929$

Barbosa JM, Eisenlohr PV, Rodrigues MA, Barbosa KC. Ecologia da dispersão de sementes em florestas tropicais. In: Martins SV, editor. Ecologia de florestas tropicais do Brasil. 2nd ed. Viçosa: Editora UFV; 2012. p. 85-106.

Booth BD, Larson DW. The role of seed rain in determining the assembly of a cliff community. Journal of Vegetation Science 1998; 9(5): 657-668. 10.2307/3237284

Brazilian Flora 2020. Rio de Janeiro Botanical Garden [Internet]. 2017 [cited 2017 May 18]. Available from: http://floradobrasil.jbrj.gov.br

Brown S, Lugo AE. Tropical secondary forests. Journal of Tropical Ecology 1990; 6(1): 1-32. 10.1017/S0266467400003989

Chazdon RL. Tropical forest regeneration. In: Levin SA, editor. Encyclopedia of Biodiversity. 2nd ed. Oxford: Elsevier; 2013. p. 277-286.

Chazdon RL, Letcher SG, van Breugel M, Martínez-Ramos M, Bongers F, Finegan B. Rates of change in tree communities of secondary Neotropical forests following major disturbances. Philosophical Transactions of the Royal Society of London B: Biological Sciences 2007; 362(1478): 273-289. 10.1098/rstb.2006.1990

ClarkCJ,Poulsen JR, ParkerVT. The role of arboreal seed dispersalgroups on the seed rain of a Lowland Tropical Forest. Biotropica 2001; 33(4): 606-620. 10.1646/0006-3606(2001)033[0606:TROASD]2.0.CO;2

Climate-Data. Climate data for cities worldwide: Nova Lima, Minas Gerais, Brazil [Internet]. [2017?] [cited 2017 May 17]. Available from: https://en.climate-data.org

Fenner MW. Seed ecology. Dordrecht: Springer Netherlands; 1985.

Ferreira PI, Gomes JP, Batista F, Bernardi AP, Costa NCF, Bortoluzzi RLC, Mantovani A. Espécies potenciais para recuperação de áreas de preservação permanente no Planalto Catarinense. Floresta e Ambiente 2013; 20(2): 173-182. 10.4322/floram.2013.003

Gandolfi S, Leitão-Filho HF, Bezerra CLF. Levantamento florístico e caráter sucessional das espécies arbustivo-arbóreas de uma floresta mesófila semidecídua no município de Guarulhos, SP. Revista Brasileira de Botânica de Botânica 1995; 55(4): 753-767.

Guaratini MTG, Gomes EPC, Tamashiro JY, Rodrigues RR. Composição florística da Reserva Municipal de Santa Genebra, Campinas, SP. Revista Brasileira de Botânica 2008; 31(2): 323-337. 10.1590/S0100-84042008000200015
Holl KD. Factors limiting tropical rain forest regeneration in abandoned pasture: seed rain, seed germination, microclimate, and soil. Biotropica 1999; 31(2): 229-242. 10.1111/j.1744-7429.1999. tb00135.x

Holl KD, Loik ME, Lin EHV, Samuels IA. Tropical montane forest restoration in Costa Rica: overcoming barriers to dispersal and establishment. Restoration Ecology 2000; 8(4): 339-349. 10.1046/j.1526-100x.2000.80049.x

Londe V, Sousa HC, Kozovits AR. Exotic and invasive species compromise the seed bank and seed rain dynamics in forests undergoing restoration at urban regions. Journal of Forestry Research 2017; 28(5): 1019-1026. 10.1007/s11676-017-0370-2

Magnago LFS, Martins SV, Venzke TS, Ivanauskas NM. Os processos e estágios sucessionais da Mata Atlântica como referência para a restauração florestal. In: Martins SV, editor. Restauração ecológica de ecossistemas degradados. Viçosa: Editora UFV; 2012. p. 69-100.

Magurran AE. Measuring biological diversity. Oxford: Blackwell Publishing; 2004.

Martins SV. Recuperação de matas ciliares. 2nd ed. Viçosa: Aprenda Fácil; 2011.

Metzger JP. Tree functional group richness and landscape structure in a Brazilian tropical fragmented landscape. Ecological Applications 2000; 10(4): 1147-1161. 10.1890/1051-0761(2000)010[1147:TFGRAL]2.0.CO;2

Mitri GH, Gitas IZ. Mapping post-fire forest regeneration and vegetation recovery using a combination of very high spatial resolution and hyperspectral satellite imagery. International Journal of Applied Earth Observation and Geoinformation 2013; 20: 60-66. 10.1016/j.jag.2011.09.001

Penhalber EF, Vani WM. Flowering and seed rain in a secondary forest in São Paulo, southeastern Brazil. Brazilian Journal of Botany 1997; 20(2): 205-220. 10.1590/S0100-84041997000200011

Piña-Rodrigues FCM, Aoki J. Seed rain as indicator of forest fragment conservation in Sorocaba, São Paulo State. Ciência Florestal 2014; 24(4): 911-923. 10.5902/1980509816603

Pivello VR, Petenon D, Jesus FM, Meirelles ST, Vidal MM, Alonso RAS, Franco GADC et al. Chuva de sementes em fragmentos de Floresta Atlântica (São Paulo, SP, Brasil), sob diferentes situações de conectividade, estrutura florestal e proximidade da borda. Acta Botanica Brasilica 2006; 20(4): 845-859. 10.1590/S010233062006000400010

Rathcke B, Lacey EP. Phenological patterns of terrestrial plants. Annual Review of Ecology and Systematics 1985; 16(1): 179-214. 10.1146/annurev.es.16.110185.001143

Ricklefs RE. The economy of nature. 6th ed. New York: W.H. Freeman and Company; 2008.

Rizzini CT. Tratado de fitogeografia do Brasil: aspectos ecológicos, sociológicos eflorísticos 2nd ed. Rio de Janeiro: Âmbito Cultural; 1997.

Rodrigues RR, Gandolfi S. Conceitos, tendências e ações para a recuperação de florestas ciliares. In: Rodrigues RR, Leitão Filho HF, editors. Matas ciliares: conservação e recuperação. 2nd ed. São Paulo: Edusp; 2004. p. 235-248. 
Silva RKS, Feliciano ALP, Marangon LC, Lima RB, Santos WB. Estrutura e síndromes de dispersão de espécies arbóreas em um trecho de mata ciliar, Sirinhaém, Pernambuco, Brasil. Pesquisa Florestal Brasileira 2012; 32(69): 1-12. 10.4336/2012.pfb.32.69.01

Turner MG, Romme WH. Landscape dynamics in crown fire ecosystems. Landscape Ecology 1994; 9(1): 59-77. 10.1007/ BF00135079
Vibrans, AC, Sevegnani L, Uhlmann A, Schorn LA, Sobral MG, Gasper AL, Lingner DV et al. Structure of mixed ombrophyllous forests with Araucaria angustifolia (Araucariaceae) under external stress in Southern Brazil. Revista de Biología Tropical 2011; 59(3): 1371-1387.

Young KR, Ewel JJ, Brown BJ. Seed dynamics during forest succession in Costa Rica. Vegetatio 1987; 71(3): 157-173. 10.1007/BF00039168 